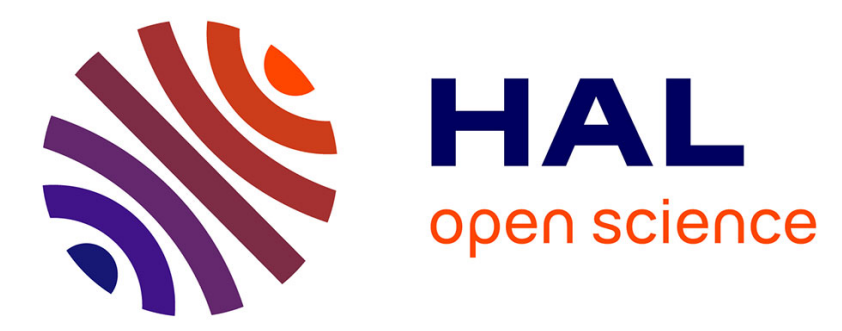

\title{
Aerobic microbial activity in four tropical earthworm-soil systems. A mesocosm experiment
}

Jorge J. Sierra, Gladys Loranger-Merciris, Lucienne Desfontaines, Maryline

Boval

\section{- To cite this version:}

Jorge J. Sierra, Gladys Loranger-Merciris, Lucienne Desfontaines, Maryline Boval. Aerobic microbial activity in four tropical earthworm-soil systems. A mesocosm experiment. Soil Research, 2014, 52 (6), pp.584-592. 10.1071/SR14034 . hal-02631073

\section{HAL Id: hal-02631073 \\ https://hal.inrae.fr/hal-02631073}

Submitted on 27 May 2020

HAL is a multi-disciplinary open access archive for the deposit and dissemination of scientific research documents, whether they are published or not. The documents may come from teaching and research institutions in France or abroad, or from public or private research centers.
L'archive ouverte pluridisciplinaire HAL, est destinée au dépôt et à la diffusion de documents scientifiques de niveau recherche, publiés ou non, émanant des établissements d'enseignement et de recherche français ou étrangers, des laboratoires publics ou privés. 
1 Aerobic microbial activity in four tropical earthworm-soil systems. A mesocosm 2 experiment

3 Running head: Microbial activity in earthworm-soil systems

4

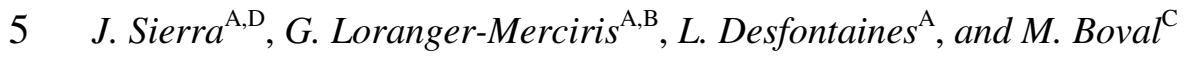

6

7 A INRA, UR1321, ASTRO Agrosystèmes Tropicaux, F-97170, Petit-Bourg, Guadeloupe, France

8 B Université des Antilles et de la Guyane, UFR Sciences Exactes et Naturelles, Campus de Fouillole, F-

9 97157, Pointe-à-Pitre, Guadeloupe, France

10 CINRA, UR143, URZ Unité de Recherches Zootechniques, F-97170, Petit Bourg, Guadeloupe, France

$11 \quad{ }^{\mathrm{D}}$ Corresponding author. Email: jorge.sierra@antilles.inra.fr 

experiment

Abstract. Soil organic matter (SOM) quality and carbon (C) availability may be major features affecting the effect of earthworms on the aerobic processes in clayey tropical soils. In this study, we assessed the effect of an anecic (Polypheretima elongata), an endogeic (Pontoscolex corethrurus) and an epigeic (Eudrilus eugeniae) earthworm on the aerobic microbial activity of two tropical soils, a calcic vertisol and an acid ferralsol, with clay content $>70 \%$ and very different organic $\mathrm{C}$ content and SOM stability. The soil-earthworm interaction was studied in a 6-month mesocosm experiment in a greenhouse using soils with and without (control soil) earthworm addition. Potential C mineralization, actual net nitrogen $(\mathrm{N})$ mineralization and dehydrogenase activity (DHA), as indicators of the aerobic activity of the soils, and phosphorus (P) availability were determined during the trial. DHA was used as an indicator of the global aerobic activity. Earthworms affected little potential $\mathrm{C}$ mineralization but increased significantly actual net $\mathrm{N}$ mineralization. The increase of $\mathrm{N}$ mineralization in the vertisol was twice as great as, and longer (6 months vs. 3 months) than for the ferralsol. Differences between soils for $\mathrm{N}$ mineralization were associated with a less recalcitrant $\mathrm{SOM}$ in the vertisol. Available $\mathrm{P}$ increased $10 \%$ in the earthworm treatments. Earthworm activity improved $\mathrm{N}$ and P availability. DHA was 15 times higher for the vertisol than for the ferralsol, but the positive effect of earthworms on DHA was greater for the ferralsol. This effect was greater for E. eugeniae probably due to surface burrows generated by this epigeic earthworm, which favoured oxygen entry into the soil. Differences between the two soils were greater for DHA than for $\mathrm{C}$ and $\mathrm{N}$ mineralization, and this was observed for the control soils as well as for the earthworm treatments. This indicates that earthworm activity modified the rate of the aerobic processes but it did not affect the intrinsic biological properties of these tropical soils, which were controlled mainly by SOM quality and C availability.

Additional keywords: Eudrilus eugeniae, ferralsol, Polypheretima elongata, Pontoscolex corethrurus, SOM mineralization, vertisol.

\section{Introduction}

Earthworms contribute to many ecosystem services, including water regulation, nutrient cycling, carbon (C) sequestration and primary production (Blouin et al. 2013). Eearthworm species and populations vary widely with the ecosystem management, such as differences in tillage, nutrient and pesticide inputs, and crop rotation (Lavelle 2002). The intensive cropping systems developed since about 1980 in the Caribbean region are based on heavy use of fertilizers and pesticides, which cause severe diffuse pollution of water resources and reduce soil fauna and biodiversity (Charlier et al. 
2009). As an example, Clermont-Dauphin et al. (2004) reported that microbial activity and earthworm biomass in the soils of that region decreased drastically under intensive banana monocropping.

Blouin et al. (2013) proposed a theoretical approach to assess the impact of practices including earthworms on ecosystem services. These practices vary according to a gradient from passive biostimulation (e.g. removal of management practices detrimental to earthworms) to active biostimulation (e.g. vermicomposting, inoculation in the field). This approach may be considered as a conceptual tool to identify different management techniques to preserve or to improve ecosystem behaviour. Recently, it has been reported that earthworms in a tropical leptosol enhance the stabilization of soil organic matter only when organic residues are applied (Fonte and Six 2010). In this case, changes in management systems are probably a better way of manipulating carbon sequestration in agricultural contexts than the inoculation of earthworms. Indeed, the most effective use of earthworms to improve soil quality requires a detailed understanding of the interaction between soils properties and earthworm activity (Lavelle and Spain 2001). McInerney and Bolger (2000) assessed the effect of temperature, wetting cycles and soil texture on $\mathrm{C}$ and nitrogen $(\mathrm{N})$ dynamics in earthworm casts in temperate soils. They observed a strong protection of $\mathrm{C}$ and $\mathrm{N}$ in casts at first, followed by a reduction in protection due to weakening of aggregate structure. The extent of the protection phase depended on complex interactions between the three studied factors. Similar results were obtained by McInerney et al. (2001) who observed that earthworm reworking of soil may cause pulses of mineralization and reduce $\mathrm{C}$ stability inside clay-rich casts. Moreover, Marhan and Scheu (2005) found that $\mathrm{C}$ mineralization in casts prevailed on $\mathrm{C}$ stabilisation, and this was further stimulated by the addition of sand in soils. For a tropical ferralsol, Chapuis-Lardy et al. (2010) reported that earthworm activity increased $\mathrm{C}$ mineralization in the short term. The same observation was made by Bernier (1998) in a forest soil of the French Alps for anecic and endogeic earthworms.

Earthworms are currently classified in three main functional groups: epigeic living at the topsoil, endogeic living near the soil surface, and the deep-burrowing anecic species (Sheehan et al. 2007). Anecic earthworms are larger than topsoil species, feeding on larger quantities of organic matter on the soil surface, having the potential to incorporate this deeper in the soil profile. Another classification based on feeding habits places epigeic and anecic earthworms into the group of detritivores, with a regime based on plant litter and mammalian dung, and the endogeic earthworms in the group of geophages, which derive their nutrition from soil organic matter (SOM) and dead roots (Curry and Schmidt 2007). Indeed, contradictory results concerning the effect of earthworm activity on soil $\mathrm{C}$ and $\mathrm{N}$ dynamics could be attributed to differences between earthworm species in soil location and feeding habits. However, Lavelle et al. (2004) highlight that earthworms may not always exhibit the behaviour associated to their functional group, and that a classification based more on impacts on soil parameters might be more useful. This is particularly important in the Caribbean region where climatic gradients on small spatial scales (i.e. $10 \mathrm{~km}$ ) and volcanic activity have led to a great diversity of clayey soils with very different soil mineralogy, C content and SOM quality, which may strongly affect earthworm behaviour and functions (Clermont-Dauphin et al. 2004; Sierra 2006). 
In this study, we tested the hypothesis that the effect of earthworm activity in these soils is mainly controlled by SOM quality and C availability, which depends upon the strength of SOM stabilization with the specific clay fraction of each soil group. For this, we assessed the effect of an anecic, an endogeic and an epigeic earthworm species on $\mathrm{C}$ and $\mathrm{N}$ mineralization and on the total aerobic microbial activity of two tropical soils of Guadeloupe (vertisol and ferralsol) with very different mineralogy, SOM quality and C availability. This study is part of a larger project devoted to improve soil quality in the Caribbean region using earthworm inoculation in crop (Lafont et al. 2007; Loranger-Merciris et al. 2012) and grassland (d'Alexis et al. 2009) systems. These studies were carried out on the same vertisol and ferralsol used in the present study. So the aim of this work was to analyse how active biostimulation by inoculation of earthworms affects some key aerobic processes in these tropical soils.

\section{Materials and methods}

\section{Rationale of the experimental design}

For this study we selected an acid dark red ferralsol and a calcic vertisol (FAO Unesco 2006), with very different SOM content and SOM stability. These factors may greatly affect earthworm activity (Barot et al. 2007; Blouin et al. 2013). SOM content is lower in the ferralsol and it is very recalcitrant. Most of SOM may be considered as inert at the time scale of this study. This fraction corresponds to SOM complexed with active $\mathrm{Fe}$ and $\mathrm{Al}$ sesquioxides and has a mean residence time of 2000-5000 years (Sierra et al. 2010). SOM in the vertisol is complexed with smectite, but the labile SOM fraction is greater than that in the ferralsol, and then $\mathrm{C}$ availability is also greater in that soil (Sierra et al. 2002). These soil properties should allow to test the hypothesis relative to the effect of SOM quality and $\mathrm{C}$ availability on earthworm activity. Similarly, the effect of earthworm was assessed using a relatively long term mesocosm experiment (i.e. 6 months), which is required to better understand the influence of earthworms on SOM dynamic. Earthworm species used in our mesocosm experiment are already present in soils under natural conditions, at the density set in the experiment. In this way, we assume that a part of SOM characteristics of each soil are also associated to the specific earthworm activity.

We used three earthworm species: Polypheretima elongata (Perrier), Pontoscolex corethrurus (Muller), and Eudrilus eugeniae (Kinberg). Earthworm treatments were defined considering the species observed in each soil to take into account earthworm adaptation to specific soil characteristics. In fact, preliminary work indicated a high death rate of $P$. elongata when it was inoculated in the ferralsol, and the same was observed for P. corethrurus in the vertisol. In this way, although $E$. eugeniae was observed and used in both soils, P. elongata was observed and used only in the vertisol, and $P$. corethrurus was observed and used only in the ferralsol. 
To assess the effect of earthworm activity, we used two indicators linked to SOM mineralization. The first indicator involved the measurement of $\mathrm{C}$ respiration from laboratory incubations, which reflected the potential of soil $\mathrm{C}$ mineralization at the moment of soil sampling. The term potential implies that $\mathrm{C}$ mineralization was measured under optimal environmental conditions for specific enzymes (i.e. soil temperature and moisture content). The second indicator involved the assessment of the time course of soil mineral $\mathrm{N}$ in the soil-earthworm systems placed under greenhouse conditions (mesocosm experiment). Because $\mathrm{N}$ inputs, water drainage and nitrate leaching did not occur in our soil-earthworm systems, the time course of mineral $\mathrm{N}$ reflected the actual cumulative net $\mathrm{N}$ mineralization during the experiment. Dehydrogenase activity (DHA) was also determined at each sampling date as an indicator of the average activity of the active aerobic microbial population (Tabatabai 1994; Tiquia 2005). In this way, we assessed the effect of earthworm activity on specific aerobic processes ( $\mathrm{C}$ and $\mathrm{N}$ mineralization) and also on the total aerobic microbial activity (DHA). The effect of earthworm activity on exchangeable cations and available P content was also determined because they may represent constraints for microbial activity, mainly in the ferralsol (Sierra 2006).

140

\section{Soils and earthworms}

142

143 The soils are located at the experimental stations of the Institut National de la Recherche 144 Agronomique in Guadeloupe (French West Indies). The ferralsol is located at the Duclos experimental station $\left(16^{\circ} 12^{\prime} \mathrm{N}, 61^{\circ} 40^{\prime} \mathrm{W}\right.$, mean annual air temperature $25.5^{\circ} \mathrm{C}$, mean annual rainfall $\left.3000 \mathrm{~mm}\right)$, and the vertisol is located at the Gardel experimental station $\left(16^{\circ} 17^{\prime} \mathrm{N}, 61^{\circ} 21^{\prime} \mathrm{W}\right.$, mean annual air temperature $27^{\circ} \mathrm{C}$, mean annual rainfall $1100 \mathrm{~mm}$ ). Both soils are under natural grassland of

148 Dichanthium aristatum (Poir) C.E. Hubbard for forty years. Some characteristics of the 0-0.2 m layer of the soils are presented in Table 1. The ferralsol was developed on old volcanic ash deposits and the clay fraction is dominated by kaolinite and sesquioxides of Fe and Al. The vertisol was developed on coral reef limestone and the clay fraction is dominated by smectite.

P. elongata (anecic earthworm) and P. corethrurus (endogeic earthworm) are considered to be continuous breeders with high fecundity in tropical soils (Bhattacharjee and Chaudhuri 2002). Both species are frequently detected in grasslands of Guadeloupe, in vertisols for P. elongata and in ferralsols for P. corethrurus. E. eugeniae is a fast-growing epigeic earthworm (Lim et al. 2012). In Guadeloupe it was observed in ferralsols and vertisols in the topsoil layer of grasslands covered with

157 leaf litter, and also in mounds of cattle manure. In this study, P. elongata and P. corethrurus were 158 collected from grassland soils and E. eugeniae was collected from a mound of manure stored at the 159 Duclos Experimental Station.

160 
163

164

165

166

167

168

169

170

171

172

173

174

175

176

177

178

179

180

181

182

183

184

185

186

187

188

189

190

191

192

193

194 Carbon mineralization was determined by short-term soil incubation using the procedure described by 195 Sierra et al. (2013). For incubation, $20 \mathrm{~g}$ soil (dry matter basis) was placed in $50 \mathrm{~mL}$ glass vials. One 196 vial containing the soil sample, one vial of distilled water, and one vial containing $1 \mathrm{~m} \mathrm{NaOH}$ solution 197

Soil samples were collected by removing the upper $0.2 \mathrm{~m}$ layer of a $1.2 \mathrm{~m}$ by $1.2 \mathrm{~m}$ quadrat within the grassland plots. The soils were ground manually to reduce aggregates to $<5 \mathrm{~mm}$; large grass roots were removed manually and fine roots were removed using tweezers. After this, the soils were homogenized and gently air-dried to obtain a water content of $0.25 \mathrm{~kg} / \mathrm{kg}$ for the ferralsol and 0.35 $\mathrm{kg} / \mathrm{kg}$ for the vertisol. A 2-kg sample of each soil was separated for the chemical and biological measurements at time 0 (T0). These samples were stored at $4^{\circ} \mathrm{C}$ for $48 \mathrm{~h}$ before being used for analyses. After this, $18 \mathrm{~kg}$ (dry matter basis) of the soils was placed in 15-L plastic pots $(0.3 \mathrm{~m}$ diameter, $0.3 \mathrm{~m}$ deep) and moistened to $-30 \mathrm{kPa}(0.31 \mathrm{~kg} / \mathrm{kg}$ for the ferralsol and $0.44 \mathrm{~kg} / \mathrm{kg}$ for the vertisol). Twenty earthworms were added to each pot. Earthworm biomass was about $20 \mathrm{~g}$ per pot for P. corethrurus, $22 \mathrm{~g}$ per pot for E. eugeniae, and $44 \mathrm{~g}$ per pot for P. elongata. This is equivalent to 300 earthworms $/ \mathrm{m}^{2}$, which is the mean density observed for several extensive pastures in Guadeloupe. The pots were covered with a plastic perforated net to keep out the earthworm predators present locally such as centipedes and frogs.

There were 6 treatments: (i) control vertisol (without earthworm addition, called V), (ii) vertisol with addition of $P$. elongata $(\mathrm{V}+\mathrm{Pe})$, (iii) vertisol with addition of E. eugeniae ( $\mathrm{V}+\mathrm{Ee})$, (iv) control ferralsol (F), (v) ferralsol with addition of P. corethrurus $(\mathrm{F}+\mathrm{Pc})$, and (vi) ferralsol with addition of E. eugeniae $(\mathrm{F}+\mathrm{Ee})$. There were 4 replicates of each treatment. The 24 pots were placed for 6 months in a greenhouse, and arranged in a fully randomised design. Soil moisture in the pots was kept at $-30 \mathrm{kPa}$ throughout the trial by regular weighing and topping up. Mean daily temperature in the greenhouse varied between $26^{\circ} \mathrm{C}$ and $28^{\circ} \mathrm{C}$.

The soil in the pots was sampled 3 (T3) and 6 (T6) months after the beginning of the trial. Soil cores were taken from the soil surface to the bottom of the pots $(0.27 \mathrm{~m})$ using a $0.1 \mathrm{~m}$ diameter auger. The hole made by soil sampling at $\mathrm{T} 3$ was filled with a $0.1 \mathrm{~m}$ diameter polystyrene cylinder to minimize the effect of soil disruption on microbial and earthworm activity around the sampling site. For the same reason, soil sampling at T3 and at T6 was done on opposite sides of the pots. Soil samples were homogenized and stored at $4^{\circ} \mathrm{C}$ for $48 \mathrm{~h}$ before being used for analyses. The number and the biomass of earthworms were determined in the soil remaining in the pots at the end of the experiment.

\section{Carbon mineralization}

were placed in $0.5-\mathrm{L}$ glass jars. The vial containing water was used to ensure water saturation of the air inside the jars and thus prevent soil drying during the incubation. Two soil incubations were carried out for each soil sample (i.e. 2 pseudo-replicates for each replicate and 48 soil incubations per sampling date). After this, all of the jars were placed in the dark at a constant temperature of $30^{\circ} \mathrm{C}$ for 
21 days. Carbon mineralization was measured at 1, 2, 3, 7, 14 and $21 \mathrm{~d}$ from the beginning of the incubation. The $\mathrm{CO}_{2}$ produced between two measurement dates and trapped in the $\mathrm{NaOH}$ solution was back-titrated with $0.4 \mathrm{~m} \mathrm{HCl}$. After this, the vial containing the $\mathrm{NaOH}$ solution was renewed to prevent saturation of the solution. Soil moisture was checked by weighing at each measurement date.

Chemical and dehydrogenase activity analyses

Approximately $200 \mathrm{~g}$ of each soil sample was dried at $60^{\circ} \mathrm{C}$ for $72 \mathrm{~h}$ for chemical and DHA analyses. Four sub-samples ground to $<0.2 \mathrm{~mm}$ were used to determine total $\mathrm{C}$ and $\mathrm{N}$, and DHA for all the treatments and sampling dates. Total $\mathrm{C}$ and $\mathrm{N}$ were determined using an element analyser (NC 2100 Soil, CE Instruments, Italy). DHA was determined following the procedure described by Tabatabai (1994), and expressed as the amount of triphenyl formazan (TPF) produced with reference to the calibration curve prepared from TPF standard.

Four sub-samples ground to $<2 \mathrm{~mm}$ were used to determine $\mathrm{pH}$ (soil : water $1: 5 \mathrm{w} / \mathrm{v}$ ), exchangeable cations and available $\mathrm{P}$. Exchangeable cations were extracted using a $1 \mathrm{~N} \mathrm{NH}_{4} \mathrm{OAc}$ solution at $\mathrm{pH} 7$, and measured by atomic absorption spectrophotometry (AAFS 240, Varian, France). Available $\mathrm{P}$ was determined using the Olsen-Dabin method in a mixture of $0.5 \mathrm{~N} \mathrm{NaHCO}_{3}$ and $0.5 \mathrm{~N}$ $\mathrm{NH}_{4} \mathrm{~F}$ at $\mathrm{pH} 8.5$ (Morel and Fardeau 1987). Nitrate-N and $\mathrm{NH}_{4}-\mathrm{N}$ were extracted from $20 \mathrm{~g}$ of moist samples by shaking for $24 \mathrm{~h}$ with $100 \mathrm{~mL}$ of $0.5 \mathrm{M} \mathrm{KCl}$, and centrifuging, and measured with a continuous flow colorimeter (AutoAnalyzer 3, Bran Luebbe, France). Mineral N analyses were made in duplicate. Mineral $\mathrm{N}$ content was used to assess net $\mathrm{N}$ mineralization in the pots.

\section{Statistical analyses}

Differences between treatments and sampling dates for the chemical and biological soil properties were assessed by analysis of variance (ANOVA) followed by Tukey's test, with a two-way design (i.e. earthworm treatment $X$ sampling date) with 4 independent replicates per earthworm treatment and date (i.e. replicates from 4 pots). Because variance was significantly different between soil treatments, ANOVA was performed separately for each soil. Differences between soils were then assessed using a $t$-test with different variance. For $\mathrm{C}$ mineralization, ANOVA was performed using the cumulative mineralized $\mathrm{C}$ on day $21\left(\mathrm{Cmin}_{21}\right)$. The analyses were performed using SAS v. 9.1 software (SAS Institute 1999). The confidence level was fixed at $P=0.05$ for all the analyses.

\section{Results}


The kinetics of $\mathrm{C}$ mineralization was similar for all the treatments, with the highest rates occurring during the first week of soil incubation (Fig. 1). The coefficient of variation (CV) of cumulated C mineralization was relatively small for all the treatments and averaged $7 \%$ throughout the soil incubations. $\mathrm{Cmin}_{21}$ was higher for the vertisol than for the ferralsol treatments for all the sampling dates and all the earthworm treatments (Fig. 2). $\mathrm{Cmin}_{21}$ decreased significantly with the sampling date in both soil treatments, and the decrease was greater for the ferralsol treatments ( $-80 \%$ from $\mathrm{T} 0$ to $\mathrm{T} 6$ ) than for the vertisol treatments $(-55 \%)$. For both soils, the effect of earthworms on $\mathrm{Cmin}_{21}$ was only noticeable at $\mathrm{T} 3$, but the trend of the earthworm effect was different for each soil. For example, the treatment with E. eugeniae had the lowest $\mathrm{Cmin}_{21}$ for the vertisol (Fig. 2a), and the highest $\mathrm{Cmin}_{21}$ for the ferralsol (Fig. 2b). The interaction earthworm treatment $x$ sampling date was only significant for the vertisol treatments. Relative $\mathrm{C}$ mineralization, that is $\mathrm{Cmin}_{21}$ expressed as percentage of the total $\mathrm{C}$ content of each soil, was higher for the control ferralsol than for the control vertisol at T0 (Table 2). In contrast, the values for T3 and T6 were higher for the control vertisol than for the ferralsol. The values for the earthworm treatments were similar for both soils.

The $\mathrm{CV}$ of net $\mathrm{N}$ mineralization in the mesocosm experiment was relatively small for all the treatments and averaged $10 \%$. For both soil treatments, actual net $\mathrm{N}$ mineralization was greater for the T0-T3 period than for the T3-T6 period (Fig. 3). On average, net $\mathrm{N}$ mineralization for the vertisol treatments was 3 times higher than for the ferralsol treatments. Although the rate of net $\mathrm{N}$ mineralization for the T3-T6 period decreased in both soils, it was positive for the vertisol treatments (+14 $\mathrm{mg} \mathrm{N} / \mathrm{kg}$ on average), whereas it was slightly negative for the ferralsol treatments $(-2 \mathrm{mg} \mathrm{N} / \mathrm{kg})$. For the T0-T3 period, earthworm treatments had a significant positive effect on net $\mathrm{N}$ mineralization ( $+72 \%$ for the vertisol, $+76 \%$ for the ferralsol). At the end of the experiment, the effect of earthworms was only noticeable for the vertisol $(+76 \%)$. Differences in net $\mathrm{N}$ mineralization between the two earthworm treatments of each soil, and the interaction earthworm treatment $\mathrm{X}$ sampling date were not significant throughout the experiment. At the end of the experiment, net $\mathrm{N}$ mineralization expressed as percentage of the initial organic $\mathrm{N}$ of each soil (i.e. relative net $\mathrm{N}$ mineralization) was $2.4 \%$ for the vertisol and $1.5 \%$ for the ferralsol. These values were higher in the earthworm treatments: $4.2 \%$ for the vertisol and $2.5 \%$ for the ferralsol.

Soil nutrients, $p H$, DHA and earthworm survival

Initial values of total $\mathrm{C}$ and $\mathrm{N}$, exchangeable cations, $\mathrm{CEC}$ and soil $\mathrm{pH}$ were higher for the vertisol than for the ferralsol (Table 1). For both soils, there were no effects of soil-earthworm treatments and sampling date on the level of total $\mathrm{C}$ and $\mathrm{N}$, exchangeable cations, and $\mathrm{pH}$ (Table 3). Hence values of these parameters at $\mathrm{T} 3$ and $\mathrm{T} 6$ for all the treatments were close to those presented in Table 1 for the respective initial soils. Available $\mathrm{P}$ was also much higher in the vertisol treatments (Fig. 4a,b). For the vertisol, there was a slight but significant effect of both earthworm treatments on available P, mainly 
at T6 (+10\%). For the ferralsol, only the E. eugeniae treatment had a small but significant effect at T3 and T6 $(+11 \%)$.

On average, DHA in vertisol treatments was 10 times higher than in ferralsol treatments (Fig. $4 \mathrm{c}, \mathrm{d})$. For the vertisol, DHA decreased from T0 to T3 and then it was rather stable. For this soil, no significant differences were observed between soil-earthworm treatments at T3 and T6 (Fig. 4c). For the ferralsol, DHA decreased between T0 and T3 and then increased until T6. For this soil, differences between treatments presented the same trend in $\mathrm{T} 3$ and $\mathrm{T} 6$ : $\mathrm{F}+\mathrm{Ee}>\mathrm{F}+\mathrm{Pc}>\mathrm{F}$ (Fig. 4d).

The number of earthworms in the soil remaining in the pots at the end of the experiment averaged $15.2 \pm 1.1$ without significant differences between treatments. Due to soil sampling at T3 and T6, the mass of soil remaining at the end of the experiment corresponded to about $78 \%$ of the initial amount of soil put into the pots (i.e. $18 \mathrm{~kg}$ ). Taking into account this value, the estimated recovery of earthworms was 19.5 (i.e. 15.2/0.78), which represented $97 \%$ of the initial number put into the pots (i.e. 20). For all the earthworm treatments, no significant differences were observed between the estimated recovery and the initial number of earthworms. For earthworm biomass, the estimated recovery represented $101 \pm 4 \%$ of the initial biomass, without significant differences either between treatments or in relation to the initial biomass.

\section{Discussion}

Effect of the soil and earthworms on the aerobic processes

The two major findings from this study were: (i) the effect of earthworms on the aerobic processes varied between soils as a function of SOM quality and quantity, and (ii) the potential C mineralization determined at each sampling data was not sensitive to earthworm activity and a more dynamic parameter, such as the actual net $\mathrm{N}$ mineralization, was better to evaluate the effect of earthworm activity.

Differences in absolute and relative $\mathrm{C}$ and $\mathrm{N}$ mineralization between the ferralsol and the vertisol treatments could be also due to other soil factors affecting microbial and earthworm activity. Among these factors soil $\mathrm{pH}$ and nutrient content differed strongly between soils. We think that these factors were less important that $\mathrm{C}$ availability to cause differences between soils because absolute soil respiration was relatively high at $\mathrm{T} 0$ in both soils when $\mathrm{C}$ availability was higher, and the trend of the differences in relative $\mathrm{C}$ respiration varied with time without change in $\mathrm{pH}$ or nutrient content. Similarly, although physical and mechanical properties of the ferralsol are more favourable for earthworms than those observed in the vertisol (i.e. for the ferralsol: lower bulk density, higher macroporosity, higher water availability; Sierra et al. 2002; Sierra 2006), earthworm activity was always much higher in the vertisol. In this way, although we cannot discard any effect of other soil properties, it appears that $\mathrm{C}$ availability was the major factor affecting earthworm activity in the tested 
soils. The results of earthworm recovery indicate that earthworms adapted well to the conditions of the mesocosm experiment, and suggest that the effect of earthworm turnover was a minor factor affecting soil processes.

Several authors reported that relative $\mathrm{C}$ and $\mathrm{N}$ mineralization is a suitable indicator of the size of the labile fraction of SOM, and then of SOM quality and C availability for soil organisms (e.g. Fissore et al. 2013). To explain the temporal change of the relative mineralization we hypothesize that there were at least two $\mathrm{C}$ sources in the used soils: a readily mineralizable $\mathrm{C}$ derived from exudates and the turnover of dead roots of the original grassland, and a more stable $\mathrm{C}$ fraction derived from SOM. Indeed, $\mathrm{C}$ availability was greatest at the beginning of the experiment when labile and dissolved organic C (DOC) coming from grass root exudates and the products of root turnover were still present in both soils (Jiménez and Lal 2007). This was reflected by the highest relative $\mathrm{C}$ mineralization and DHA observed at $\mathrm{T} 0$ in both soils. At this time, the greater relative $\mathrm{C}$ mineralization observed in the ferralsol would indicate that labile $\mathrm{C}$ and DOC was relatively more important in this soil due to its less total C content (Jouquet et al. 2007). The reverse occurred for the absolute $\mathrm{C}$ mineralization and DHA, which were higher for the vertisol. This was due probably to its higher available C from SOM (Table 1). Higher $\mathrm{C}$ availability at $\mathrm{T} 0$ also explains the greater rate of net $\mathrm{N}$ mineralization found for the $\mathrm{T} 0$ T3 period, and why this rate was higher for the control vertisol compared with the control ferralsol.

The higher net $\mathrm{N}$ mineralization in the earthworm treatments for the T0-T3 period could be due to three factors: (i) earthworm burrowing and mixing increased the accessibility of SOM to decomposers (Shipitalo and Le Bayon 2004; Jouquet et al. 2010), (ii) SOM decomposition in earthworm guts and in the fresh casts (Blouin et al. 2013; Majeed et al. 2013), and (iii) labile C secreted by earthworms induced a priming effect leading to faster SOM mineralization (Lavelle and Spain 2001). Regardless of the underlying mechanism involved in the effect of earthworm activity, the relatively high SOM mineralization in the T0-T3 period induced a strong depletion of available C, which affected the microbial activity in each soil in a different way.

In the ferralsol, it seems that most of labile $\mathrm{C}$ and DOC coming from the original grassland were exhausted within the three first months of the experiment, and then absolute and relative $\mathrm{C}$ mineralization decreased sharply at T3 and T6. Only E. eugeniae had a small positive effect on C mineralization at $\mathrm{T} 3$ in the ferralsol, but this was not confirmed by the net $\mathrm{N}$ mineralization observed in the following T3-T6 period. For that period, the negative net $\mathrm{N}$ mineralization observed for all the

344 ferralsol treatments indicated $\mathrm{N}$ immobilization. The effect of earthworms in the ferralsol was clearer 345 for the increase of DHA, i.e. for the global aerobic activity (Tiquia 2005). Indeed, microbial C 346 turnover and stabilization of DOC coming from the original grassland could be two of the aerobic 347 processes affected by earthworm activity (Jouquet et al. 2007), which increased DHA and $\mathrm{N}$ immobilization in these ferralsol treatments.

At T3 and T6, when C coming from the original grassland was exhausted, the relative C mineralization was two times greater for the vertisol indicating higher $\mathrm{C}$ availability from the SOM source in this soil. In this way, absolute $\mathrm{C}$ mineralization as well as net $\mathrm{N}$ mineralization in the vertisol 
decreased slower and were higher than in the ferralsol. At T3, the smaller $\mathrm{Cmin}_{21}$ in the earthworm treatments of the vertisol well reflected the exhaustion of the labile $\mathrm{C}$, which agrees with their higher $\mathrm{N}$ mineralization in the T0-T3 period. It has been reported that mixing of organic matter and fine mineral particles in the intestinal tract of earthworms can contribute to the stabilization of organic matter in stable aggregates in temperate (Bernier 1998) as well as in tropical soils (Chapuis-Lardy et al. 2010). Thus, organic matter stabilization induced by earthworms could also explain the decrease in the potential $\mathrm{C}$ mineralization at $\mathrm{T} 3$ in the earthworm treatments. As net $\mathrm{N}$ mineralization in the T3-T6 period was higher for the earthworm treatments than for the control vertisol, it follows that earthworm activity in the T3-T6 period could compensate for a lower potential $\mathrm{C}$ mineralization at T3. This agrees with the results reported by McInerney et al. (2001) who observed that earthworm reworking of soil may induce $\mathrm{C}$ mineralization and reduce $\mathrm{C}$ stability in casts. Our results clearly indicate that potential $\mathrm{C}$ mineralization was less useful than net $\mathrm{N}$ mineralization to assess the effect of earthworms. Similar results were found by Chapuis-Lardy et al. (2010) to assess the effect of earthworms on $\mathrm{N}_{2} \mathrm{O}$ fluxes by using potential denitrification in a tropical ferralsol. In contrast to the ferralsol, earthworms did not affect total aerobic activity in the vertisol, no doubt due to its relatively high current level. In fact, the level of DHA observed in vertisol treatments throughout the experiment was as high as that found currently in active composts at the end of the stabilisation period (Tiquia 2005; Sierra et al. 2013).

For a tropical ferralsol, Chaudhuri et al. (2012) observed that earthworm activity increased available $\mathrm{P}$ by its effect on the mineralization of organic $\mathrm{P}$ and on the solubilization of mineral $\mathrm{P}$. Brossard et al. (1996), for a tropical vertisol, and Chapuis-Lardy et al. (1998), for a tropical ferralsol, found that mineralization and solubilization of P may occur during gut transit and continues for a few hours after egestion of the casts. Similar results were found by Pashanasi et al. (1996) and LorangerMerciris et al. (2012) for P. corethrurus in tropical soils. These results and those of $\mathrm{N}$ mineralization indicated that active biostimulation by earthworm inoculation had positive effects on available $\mathrm{P}$ and $\mathrm{N}$ contents, which could improve primary production on these soils.

\section{Soil-earthworm interactions}

Of the three earthworm species tested in this study, E. eugeniae had the largest effect; this was particularly noticeable for the ferralsol. In this soil, the effect of E. eugeniae on DHA and available P was greater than that of $P$. corethrurus. For the vertisol, differences between the two earthworm treatments were generally not significant, except for $\mathrm{C}$ mineralization, as discussed above. It is difficult to ascertain why differences between earthworm species were greater for the ferralsol. The larger effect of E. eugeniae on DHA could be due to the improvement of gaseous exchange due to the surface burrows made by this epigeic earthworm. Moreover, for tropical soils Majeed et al. (2013) observed that selective feeding by epigeic earthworms produced casts with high $\mathrm{C}$ and nutrient content, which could boost microbial activity. If this hypothesis is true for our study, the higher effect 
of the epigeic E. eugeniae on available $\mathrm{P}$ in the ferralsol could be due to selective feeding on materials enriched in this nutrient. Chaudhuri et al. (2012) proposed the same hypothesis to explain the effect of Metaphire houlleti on the available $\mathrm{P}$ in a tropical ferralsol.

Interestingly, differences between the vertisol and the ferralsol throughout the entire experiment were much larger for DHA than for $\mathrm{Cmin}_{21}$ and net $\mathrm{N}$ mineralization. This different soil pattern for DHA and SOM mineralization was observed for the control soils as well as for the earthworm treatments, so it follows that earthworm activity affected the intensity of some aerobic processes in both soils, but it did not modify the intrinsic biological characteristics of each soil. As discussed above, we hypothesize that the effect of earthworms on $\mathrm{N}$ mineralization in the ferralsol was foreshortened because of the recalcitrant quality of SOM in this soil. That is, after depletion of the C substrate coming from the original grassland, earthworms were unable to affect organic compounds strongly complexed with active $\mathrm{Al}$ and $\mathrm{Fe}$ hydrous oxides in the ferralsol. In contrast, the effect of earthworms on $\mathrm{N}$ mineralization was longer and greater in vertisol because earthworms and microorganisms used a less recalcitrant SOM continuously. Indeed, further work is required to assess the $\mathrm{C}$ balance and the factors controlling it in nutrient-limited tropical soils affected by earthworm activity. For this, it is particularly important to consider the time scale to properly estimate the role of earthworms in terms of SOM mineralization and stabilization.

\section{Acknowledgments}

410

Financial support for this research was provided by the AgriBio3 Program of the Institut National de la Recherche Agronomique (France) and funds of the Université des Antilles et de la Guyane. We thank the anonymous reviewers for their careful reading of our manuscript and their many insightful comments and suggestions. We would like to thank F. Solvar and J. Leinster for their excellent assistance with the experiments, and A. Scaife for reviewing the English manuscript.

\section{References}

Barot S, Ugolini A, Bekkal Brikci F (2007) Nutrient cycling efficiency explains the long-term effect of ecosystem engineers on primary production. Functional Ecology 21, 1-10.

Bernier N (1998) Earthworm feeding activity and development of the humus profile. Biology and Fertility of Soils 26, 215-223.

Bhattacharjee G, Chaudhuri PS (2002) Cocoon production, morphology, hatching pattern and fecundity in seven tropical earthworm species: a laboratory-based investigation. Journal of Biosciences 27, 283-294. 
Blouin M, Hodson ME, Delgado EA, Baker G, Brussaard L, Butt KR, Dai J, Dendooven L, Peres G, Tondoh JE, Cluzeau D, Brun JJ (2013) A review of earthworm impact on soil function and ecosystem services. European Journal of Soil Science 64, 161-182.

Brossard M, Lavelle P, Laurent JY (1996) Digestion of a vertisol by the endogeic earthworm Polypheretima elongata, megascolecidae, increases soil phosphate extractability. European Journal of Soil Biology 32, 107-111.

Chapuis-Lardy L, Brauman A, Bernard L, Pablo AL, Toucet J, Mano MJ, Weber L, Brunet D, Razafimbelo T, Chotte JL, Blanchart E (2010) Effect of the endogeic earthworm Pontoscolex corethrurus on the microbial structure and activity related to $\mathrm{CO}_{2}$ and $\mathrm{N}_{2} \mathrm{O}$ fluxes from a tropical soil (Madagascar). Applied Soil Ecology 45, 201-208.

Chapuis-Lardy L, Brossard M, Lavelle P, Schouller E (1998) Phosphorus transformations in a ferralsol through ingestion by Pontoscolex corethrurus, a geophagous earthworm. European Journal of Soil Biology 34, 61-67.

Charlier JB, Cattan P, Voltz M, Moussa R (2009) Transport of a nematicide in surface and groundwater in a tropical volcanic catchment. Journal of Environmental Quality 38, 10311041.

Chaudhuri PS, Pal TK, Nath S, Dey SK (2012) Effects of five earthworm species on some physicochemical properties of soil. Journal of Environmental Biology 33, 713-716.

Clermont-Dauphin C, Cabidoche YM, Meynard JM (2004) Effects of intensive monocropping of bananas on properties of volcanic soils in the uplands of the French West Indies. Soil Use and Management 20, 105-113.

Curry JP, Schmidt O (2007) The feeding ecology of earthworms - A review. Pedobiologia 50, 463477.

d'Alexis S, Loranger-Merciris G, Mahieu M, Boval M (2009) Influence of earthworms on development of the free-living stages of gastrointestinal nematodes in goat faeces. Veterinary Parasitology 163, 171-174.

FAO Unesco (2006) "World reference base for soil resources." World Soil Resources Reports 103. (FAO: Rome)

Fissore C, Giardina CP, Kolka RK (2013) Reduced substrate supply limits the temperature response of soil organic carbon decomposition. Soil Biology and Biochemistry 67, 306-311.

Fonte SJ, Six J (2010) Earthworms and litter management contributions to ecosystem services in a tropical agroforestry system. Ecological Applications 20, 1061-1073.

Jiménez JJ, Lal R (2007) Mechanisms of C sequestration in soils of Latin America. Critical Reviews in Plant Sciences 25, 337-365.

Jouquet P, Bernard-Reversat F, Bottinelli N, Orange D, Rouland-Lefèvre C, Tran Duc T, Podwojewski P (2007) Influence of changes in land use and earthworm activities on carbon and nitrogen dynamics in a steepland ecosystem in Northern Vietnam. Biology and Fertility of Soils 44, 69-77. 
465

466

467

468

469

470

471

472

473

474

475

476

477

478

479

480

481

482

483

484

485

486

487

488

489

490

491

492

493

494

495

496

497

498

499

500

501

502

Jouquet P, Plumere T, Thu TD, Rumpel C, Duc TT, Orange D (2010) The rehabilitation of tropical soils using compost and vermicompost is affected by the presence of endogeic earthworms. Applied Soil Ecology 46, 25-133.

Lafont A, Risède JM, Loranger-Merciris G, Clermont-Dauphin C, Dorel M, Rhino B, Lavelle P (2007) Effects of the earthworm Pontoscolex corethrurus on banana plants infected or not with the plant-parasitic nematode Radopholus similis. Pedobiologia 51, 311-318.

Lavelle P (2002) Functional domains in soils. Ecological Research 17, 441-450.

Lavelle P, Pashanasi B, Charpentier F, Gilot C, Rossi JP, Derouard L, Andre J, Ponge JF, Bernier N (2004) Effects of earthworms on soil organic matter and nutrient dynamics at a landscape scale over decades. In: "Eathworm Ecology" (Ed. CA Edwards) pp. 145-180. (CRC Press LLC: Boca Raton, USA)

Lavelle P, Spain AV (2001) “Soil Ecology.” (Kluwer Academic Publishers: Dordrecht)

Lim SL, Wu TY, Sim EYS, Lim PN, Clarke C (2012) Biotransformation of rice husk into organic fertilizer through vermicomposting. Ecological Engineering 41, 60-64.

Loranger-Merciris G, Cabidoche YM, Deloné B, Quénéhervé P, Ozier-Lafontaine H (2012) How earthworm activities affect banana plant response to nematode parasitism. Applied Soil Ecology 52, 1-8.

Majeed E, Miambi E, Barois I, Blanchart E, Brauman A (2013) Emissions of nitrous oxide from casts of tropical earthworms belonging to different ecological categories. Pedobiologia 56, 49-58.

Marhan S, Scheu S (2005) Effects of sand and litter availability on organic matter decomposition in soil and in casts of Lumbricus terrestris L. Geoderma 128, 155-166.

McInerney M, Bolger T (2000) Temperature, wetting cycles and soil texture effects on carbon and nitrogen dynamics in stabilized earthworms casts. Soil Biology and Biochemistry 32, 335-349.

McInerney M, Little DJ, Bolger T (2001) Effect of earthworm cast formation on the stabilization of organic matter in fine soil fractions. European Journal of Soil Biology 37, 251-254.

Morel C, Fardeau JC (1987) Available phosphorus in intertropical soils: its relation with phosphorus determined by two extraction methods (Olsen, Olsen Dabin). Agronomie Tropicale 42, 248257.

Pashanasi B, Lavelle P, Alegre J, Charpentier F (1996) Effect of the endogeic earthworm Pontoscolex corethrurus on soil chemical characteristics and plant growth in a low-input tropical agroecosystem. Soil Biology and Biochemistry 28, 801-810.

SAS Institute (1999) "SAS User's Guide." (SAS Institute: Cary)

Sheehan C, Kirwan L, Connolly J, Bolger T (2007) The effects of earthworm functional group diversity on earthworm community structure. Pedobiologia 50, 479-487.

Shipitalo MJ, Le Bayon RC (2004) Quantifying the effects of earthworm on soil aggregation and porosity. Earthworm Ecology 10, 183-200.

Sierra J (2006) A hot-spot approach applied to nitrification in tropical acid soils. Soil Biology and Biochemistry 38, 644-652. 
Sierra J, Brisson N, Ripoche D, Déqué M (2010) Modelling the impact of thermal adaptation of soil microorganisms and crop system on the dynamics of organic matter in a tropical soil under a climate change scenario. Ecological Modelling 221, 2850-2858.

Sierra J, Desfontaines L, Faverial J, Loranger-Merciris G, Boval M (2013) Composting and vermicomposting of cattle manure and green wastes under tropical conditions: carbon and nutrient balances and end-product quality. Soil Research 51, 142-151.

Sierra J, Dulormne M, Desfontaines L (2002) Soil nitrogen as affected by Gliricidia sepium in a silvopastoral system in Guadeloupe, French Antilles. Agroforestry Systems 54, 87-97.

Tabatabai MA (1994) Soil Enzymes. In: "Methods of Soil Analysis. Part 2: Microbiological and Biochemical Properties." (Eds RW Weaver et al.) pp. 775-833. (Soil Science Society of America: Wisconsin)

514 Tiquia SM (2005) Microbiological parameters as indicators of compost maturity. Journal of Applied Microbiology 99, 816-828. 


\section{Figure captions}

518 Fig. 1. Kinetics of $\mathrm{C}$ mineralization observed during soil incubations. T0, T3 and T6 indicate sampling

519 dates and correspond to 0, 3 and 6 months after the beginning of the experiment. V, vertisol; F,

520 ferralsol; Pe, Polypheretima elongata; Pc, Pontoscolex corethrurus; Ee, Eudrilus eugeniae. Vertical 521 bars indicate the standard deviation $(\mathrm{n}=4)$.

522

523 Fig. 2. Cumulative mineralized $\mathrm{C}$ at the end of soil incubations (day 21). Vertical bars indicate the 524 standard deviation $(\mathrm{n}=4)$. For each soil, the same letter on the histogram bar indicates no significant 525 differences between treatments at $P<0.05$. Differences between soils for a given sampling date were 526 significant at $P<0.05$. See Fig. 1 for explanation of treatment codes.

528 Fig. 3. Actual net $\mathrm{N}$ mineralization for the six treatments in the mesocosm experiment. Vertical bars indicate the standard deviation $(n=4)$. See Fig. 1 for explanation of treatment codes

531 Fig. 4. (a) and (b): available P, and (c) and (d): dehydrogenase activity (DHA), determined at each sampling date. Vertical bars indicate the standard deviation $(n=4)$. For each soil, the same letter on the histogram bar indicates no significant differences between treatments at $P<0.05$. Differences between soils for a given sampling date were significant at $P<0.05$. See Fig. 1 for explanation of treatment codes 
Table 1. Some characteristics of the soils used in the present study

538 For each parameter, values followed by different letter are statistically different at $P<0.05(\mathrm{n}=4)$

539

\begin{tabular}{|c|c|c|c|c|c|c|c|c|c|c|}
\hline \multirow[t]{3}{*}{ Soil } & \multirow[t]{3}{*}{$\mathrm{pH}$} & \multicolumn{2}{|c|}{ Total } & \multirow[t]{3}{*}{ CEC } & \multirow[t]{2}{*}{ K } & \multirow[t]{2}{*}{$\mathrm{Ca}$} & \multirow[t]{3}{*}{$\mathrm{Mg}$} & \multicolumn{3}{|c|}{ Particle size } \\
\hline & & $\mathrm{C}$ & $\mathrm{N}$ & & & & & $<2 \mu \mathrm{m}$ & $2-50 \mu \mathrm{m}$ & $>50 \mu \mathrm{m}$ \\
\hline & & \multicolumn{2}{|c|}{$(\mathrm{g} / \mathrm{kg})$} & & \multicolumn{2}{|c|}{$\left(\mathrm{cmol}_{\mathrm{c}} / \mathrm{kg}\right)$} & & & $(\mathrm{kg} / \mathrm{kg})$ & \\
\hline Vertisol & $7.8 \mathrm{a}$ & $52.4 \mathrm{a}$ & $3.9 \mathrm{a}$ & $52.2 \mathrm{a}$ & $1.5 \mathrm{a}$ & $45.4 \mathrm{a}$ & $2.6 \mathrm{a}$ & $0.82 \mathrm{a}$ & $0.12 b$ & $0.06 \mathrm{~b}$ \\
\hline Ferralsol & $5.5 \mathrm{~b}$ & $23.7 \mathrm{~b}$ & $2.1 \mathrm{~b}$ & $12.4 \mathrm{~b}$ & $0.1 \mathrm{~b}$ & $2.8 \mathrm{~b}$ & $0.4 \mathrm{~b}$ & $0.71 b$ & $0.18 \mathrm{a}$ & $0.11 \mathrm{a}$ \\
\hline
\end{tabular}

540

541 
Table 2. Cumulative mineralized $\mathrm{C}$ at the end of soil incubations (day 21) expressed as \% of the

Values followed by different letter are statistically different at $P<0.05(\mathrm{n}=4) . \mathrm{T} 0$, T3 and T6 correspond to 0,3 and 6 months after the beginning of the experiment. $\mathrm{V}$, vertisol; $\mathrm{F}$,

545 ferralsol; Pe, Polypheretima elongata; Pc, Pontoscolex corethrurus; Ee, Eudrilus eugeniae 546

\begin{tabular}{lcccccc}
\hline Sampling date & $\mathrm{V}$ & $\mathrm{V}+\mathrm{Pe}$ & $\mathrm{V}+\mathrm{Ee}$ & $\mathrm{F}$ & $\mathrm{F}+\mathrm{Pc}$ & $\mathrm{F}+\mathrm{Ee}$ \\
& & & & $(\%)$ & \\
\hline T0 & $1.0 \mathrm{~b}$ & & & $1.6 \mathrm{a}$ & & \\
T3 & $0.8 \mathrm{c}$ & $0.6 \mathrm{~d}$ & $0.5 \mathrm{~d}$ & $0.4 \mathrm{e}$ & $0.4 \mathrm{e}$ & $0.5 \mathrm{~d}$ \\
$\mathrm{~T} 6$ & $0.4 \mathrm{e}$ & $0.4 \mathrm{e}$ & $0.4 \mathrm{e}$ & $0.3 \mathrm{e}$ & $0.3 \mathrm{e}$ & $0.3 \mathrm{e}$ \\
\hline
\end{tabular}


Table 3. pH, total $\mathrm{C}$ and $\mathrm{N}$, and exchangeable cations determined three (T3) and six months (T6) after the beginning of the mesocosm experiment

550 For each parameter, values followed by different letter are statistically different at $P<0.05(\mathrm{n}=4)$. V, 551 vertisol; F, ferralsol; Pe, Polypheretima elongata; Pc, Pontoscolex corethrurus; Ee, Eudrilus 552 eugeniae

553

\begin{tabular}{|c|c|c|c|c|c|c|c|}
\hline \multirow[t]{3}{*}{ Treatment } & \multirow{3}{*}{$\begin{array}{c}\text { Sampling } \\
\text { date }\end{array}$} & \multirow[t]{3}{*}{$\mathrm{pH}$} & \multicolumn{2}{|c|}{ Total } & \multirow[t]{3}{*}{ K } & $\mathrm{Ca}$ & \multirow[t]{3}{*}{$\mathrm{Mg}$} \\
\hline & & & $\mathrm{C}$ & $\mathrm{N}$ & & & \\
\hline & & & \multicolumn{2}{|c|}{$(\mathrm{g} / \mathrm{kg})$} & & $\left(\mathrm{cmol}_{\mathrm{c}} / \mathrm{kg}\right)$ & \\
\hline \multirow[t]{2}{*}{ V } & $\mathrm{T} 3$ & $7.7 \mathrm{a}$ & $51.8 \mathrm{a}$ & $3.8 \mathrm{a}$ & $1.5 \mathrm{a}$ & $43.6 \mathrm{a}$ & $2.8 \mathrm{a}$ \\
\hline & T6 & $7.8 \mathrm{a}$ & $52.0 \mathrm{a}$ & $3.9 \mathrm{a}$ & $1.5 \mathrm{a}$ & $46.9 \mathrm{a}$ & $2.9 \mathrm{a}$ \\
\hline \multirow[t]{2}{*}{$\mathrm{V}+\mathrm{Pe}$} & $\mathrm{T} 3$ & $7.7 \mathrm{a}$ & $51.6 \mathrm{a}$ & $3.7 \mathrm{a}$ & $1.5 \mathrm{a}$ & $44.5 \mathrm{a}$ & $2.9 \mathrm{a}$ \\
\hline & T6 & 7.9a & $52.1 \mathrm{a}$ & $3.6 \mathrm{a}$ & $1.8 \mathrm{a}$ & $45.1 \mathrm{a}$ & $2.9 \mathrm{a}$ \\
\hline \multirow[t]{2}{*}{$\mathrm{V}+\mathrm{Ee}$} & $\mathrm{T} 3$ & $7.7 \mathrm{a}$ & $52.3 \mathrm{a}$ & $3.9 \mathrm{a}$ & $1.7 \mathrm{a}$ & $44.8 \mathrm{a}$ & $2.7 \mathrm{a}$ \\
\hline & T6 & $7.7 \mathrm{a}$ & $52.2 \mathrm{a}$ & $3.8 \mathrm{a}$ & $1.6 \mathrm{a}$ & $44.2 \mathrm{a}$ & $2.8 \mathrm{a}$ \\
\hline \multirow[t]{2}{*}{$\mathrm{F}$} & $\mathrm{T} 3$ & $5.4 \mathrm{~b}$ & $23.1 \mathrm{~b}$ & $2.0 \mathrm{~b}$ & $0.1 b$ & $2.8 \mathrm{~b}$ & $0.4 \mathrm{~b}$ \\
\hline & T6 & $5.4 \mathrm{~b}$ & $23.6 \mathrm{~b}$ & $1.9 b$ & $0.1 b$ & $2.7 b$ & $0.4 \mathrm{~b}$ \\
\hline \multirow[t]{2}{*}{$F+P c$} & $\mathrm{~T} 3$ & $5.5 b$ & $22.9 b$ & $2.2 \mathrm{~b}$ & $0.2 b$ & $2.9 \mathrm{~b}$ & $0.3 b$ \\
\hline & T6 & $5.4 b$ & $22.4 \mathrm{~b}$ & $2.3 b$ & $0.1 b$ & $3.0 \mathrm{~b}$ & $0.4 \mathrm{~b}$ \\
\hline \multirow[t]{2}{*}{$\mathrm{F}+\mathrm{Ee}$} & $\mathrm{T} 3$ & $5.4 \mathrm{~b}$ & $23.9 b$ & $2.0 \mathrm{~b}$ & $0.2 b$ & $3.1 \mathrm{~b}$ & $0.5 b$ \\
\hline & T6 & $5.4 \mathrm{~b}$ & $23.0 \mathrm{~b}$ & $2.2 \mathrm{~b}$ & $0.1 b$ & $2.9 \mathrm{~b}$ & $0.3 b$ \\
\hline
\end{tabular}

554

555 

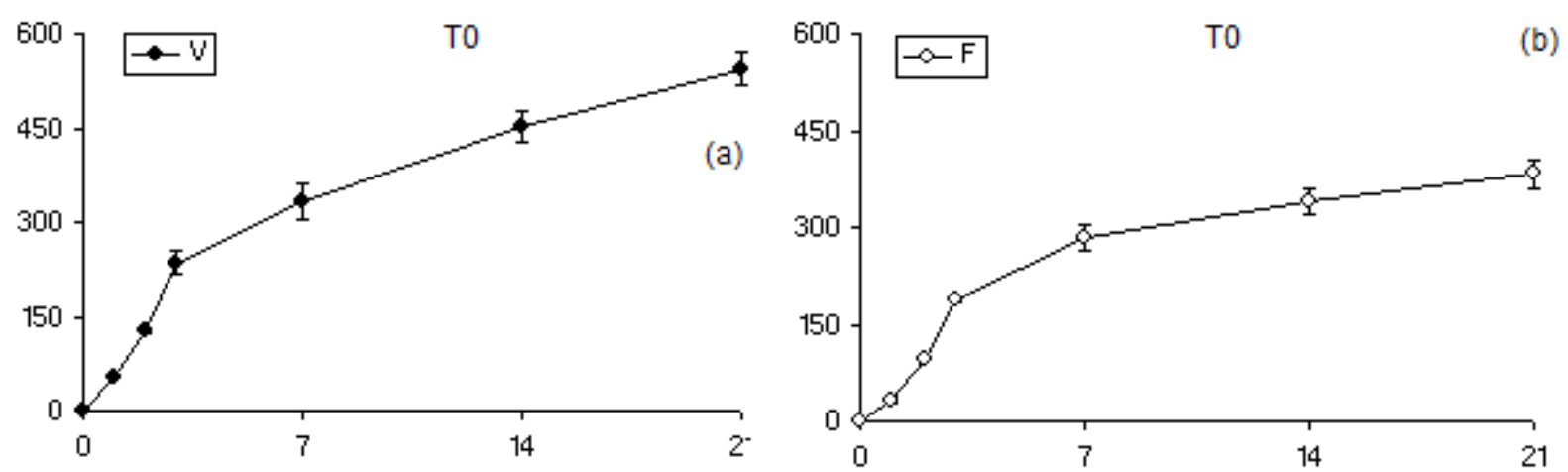

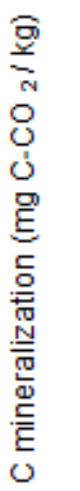
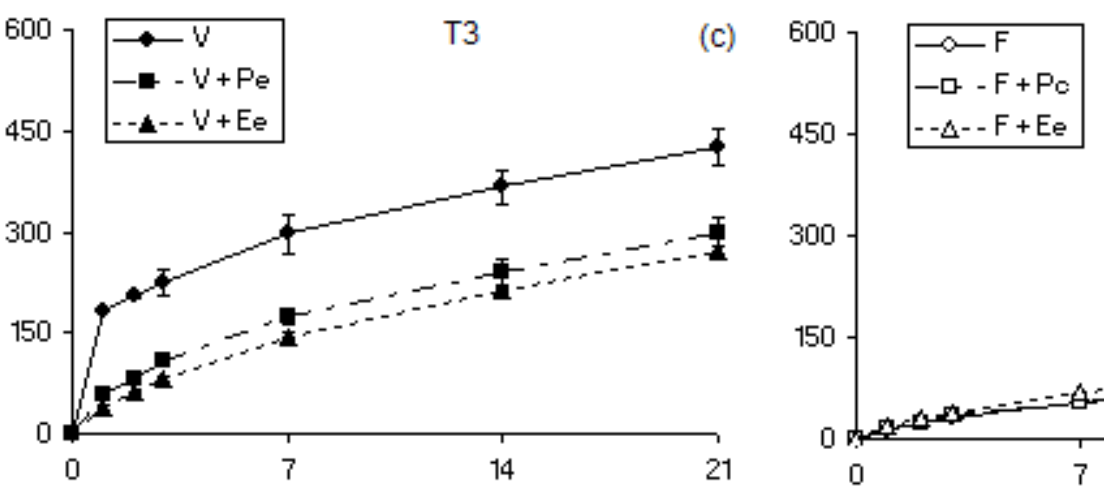

T3

(d)

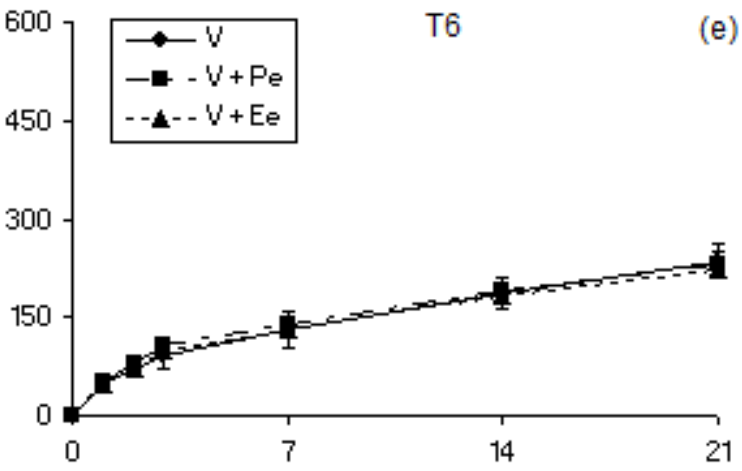

(e) 600

$450] \begin{aligned} & 600 \\ & -\infty-F \\ & -\square-F+P c \\ & -\triangle--F+E e\end{aligned}$

T6

(f)

555

556

557

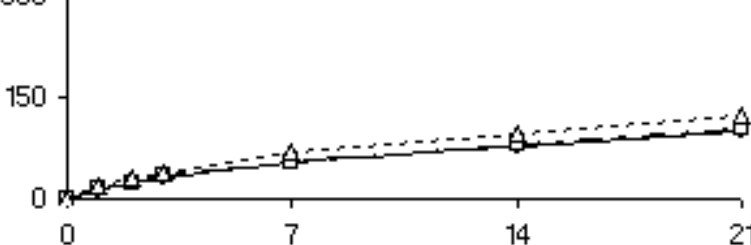

558

Fig. 1.

30

150

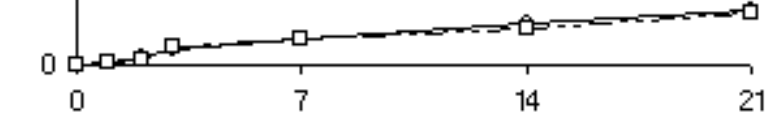

Days 

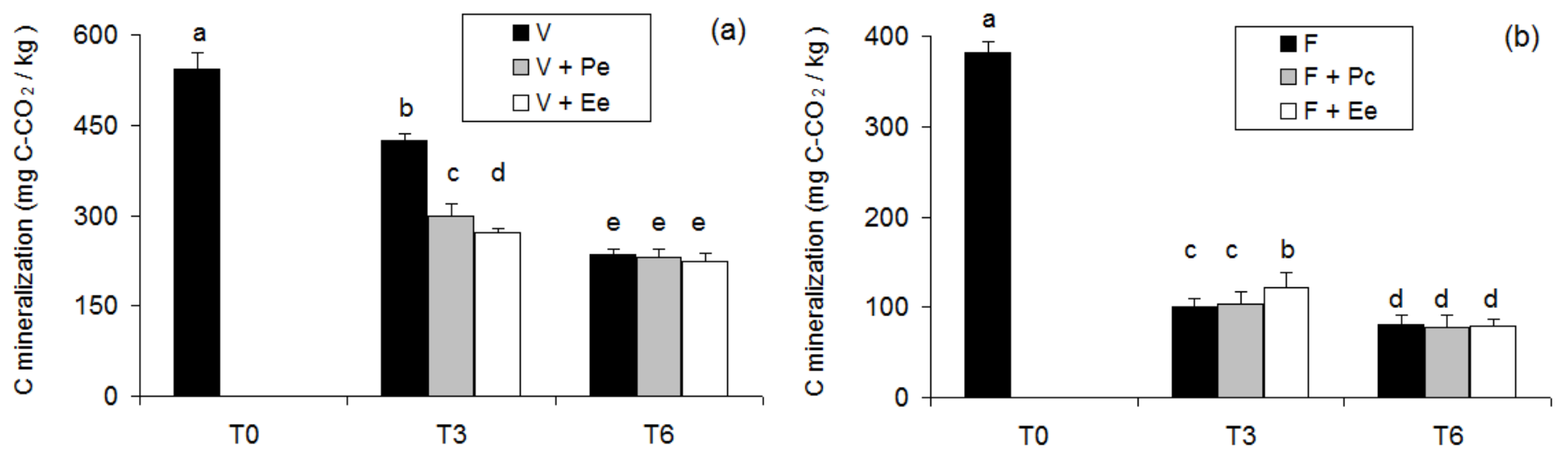

559

560

561

562

Fig. 2.

563

564

565

566

567

568 
568

569

570

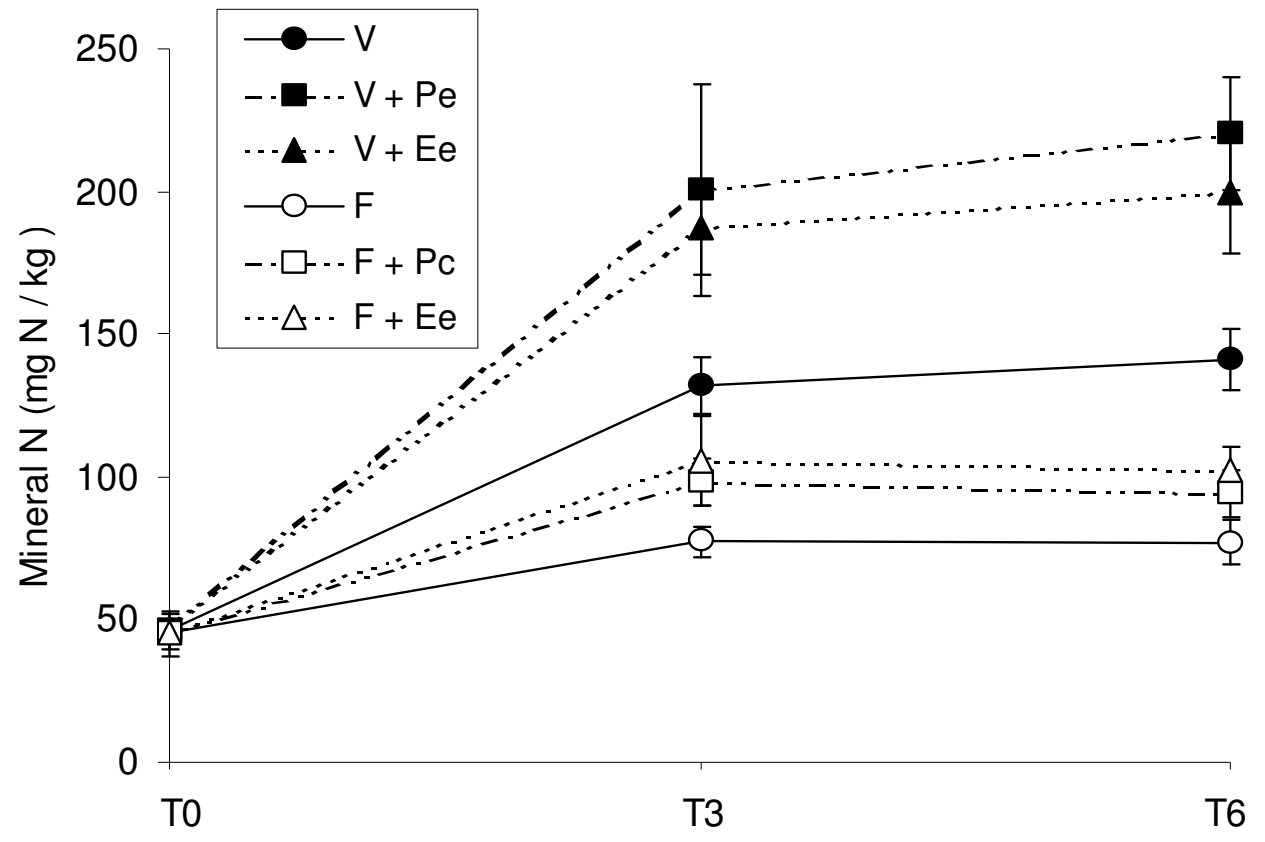

Fig. 3.

574

575

576 

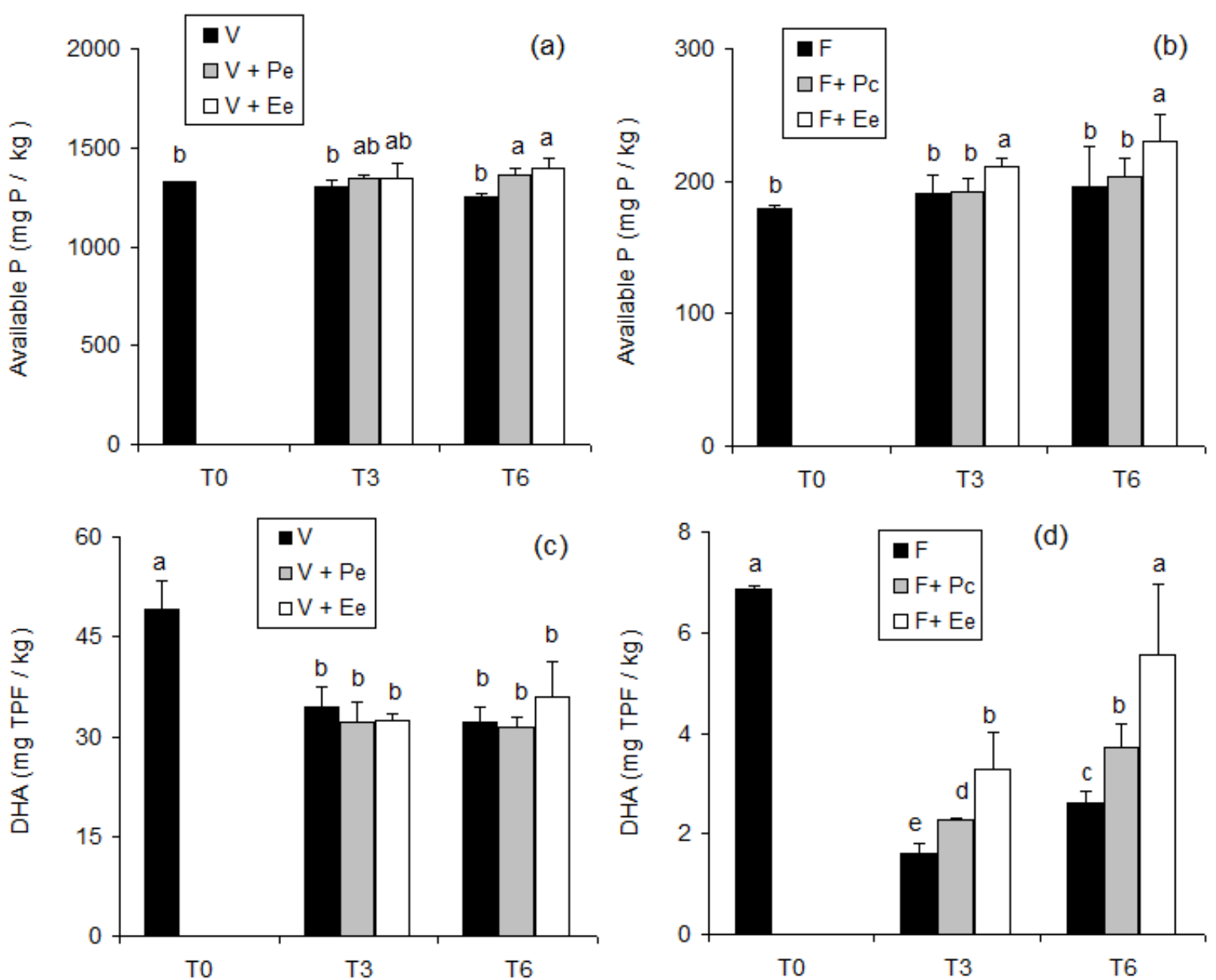

576

577

Fig. 4.

578

579 